\title{
Selecting soil quality indicators for different soil management systems in the Brazilian Cerrado
}

\author{
Diane Cristina Stefanoski(1), Cícero Célio de Figueiredo(2), \\ Glenio Guimarães Santos ${ }^{(3)}$ and Robélio Leandro Marchão(4)
}

\begin{abstract}
(1)Universidade Federal do Piauí, Campus Professora Cinobelina Elvas, BR-135, Km 03, CEP 6490-000 Bom Jesus, PI, Brazil. E-mail: diane_stefanoski@hotmail.com (2)Universidade de Brasília, Faculdade deAgronomia e Medicina Veterinária, Caixa Postal 04508, CEP70910-970 Brasília, DF, Brazil. E-mail: cicerocf@unb.br ${ }^{(3)}$ Universidade Federal de Goiás, Escola de Agronomia, Caixa Postal 131, CEP 74690-900 Goiânia, GO, Brazil. E-mail: gleniogm@gmail.com ${ }^{(4)}$ Embrapa Cerrados, BR-020, Km 18, Zona Rural, Caixa Postal 08223, Planaltina, CEP 73310-970 Brasília, DF, Brazil. E-mail: robelio.marchao@embrapa.br
\end{abstract}

\begin{abstract}
The objective of this work was to assess soil quality indicators obtained with different datasets to compare soil management systems in the Brazilian Cerrado. Three criteria were used to select soil physical, chemical, and biological indicators: the full set of indicators obtained, with 36 parameters, for which all the physical, chemical, and biological soil properties were determined; a subset of indicators selected by principal component analysis (20 parameters); and a subset of indicators with some frequency of use in the literature (16 parameters). These indicators were obtained from the following management systems: no-tillage, conventional tillage, and native cerrado vegetation. Soil samples were collected at $0.0-0.1-\mathrm{m}$ soil depth, and soil quality indicators were subjected to analysis of variance and their means were compared. The incorporation of soil native cerrado into agriculture decreased soil quality. The most commonly used indicators in the scientific literature are sensitive enough to detect differences in soil quality according to land use. Therefore, the selection of a minimum set of representative data can be more useful than a complex set of properties to compare management systems as to their soil quality.
\end{abstract}

Index terms: no-tillage, principal component analysis, soil functioning, soil health, soil management, soil security.

\section{Seleção de indicadores da qualidade do solo para diferentes sistemas de manejo do solo no Cerrado}

Resumo - O objetivo deste trabalho foi avaliar indicadores da qualidade do solo, obtidos de diferentes bases de dados, para comparar sistemas de manejo do solo no Cerrado. Três critérios foram utilizados para a seleção de indicadores físicos, químicos e biológicos do solo: o conjunto completo de indicadores obtido, com 36 parâmetros, entre os quais todas as propriedades físicas, químicas e biológicas foram determinadas; um subconjunto de indicadores selecionados por análise de componentes principais (20 parâmetros); e um subconjunto de indicadores com alguma frequência de uso na literatura (16 parâmetros). Esses indicadores foram obtidos a partir dos seguintes sistemas de manejo: plantio direto, preparo convencional e cerrado nativo. As amostras de solo foram coletadas a $0,0-0,1 \mathrm{~m}$ de profundidade, e os indicadores de qualidade do solo foram submetidos à análise de variância e suas médias foram comparadas. A incorporação do solo de cerrado nativo à agricultura diminuiu a qualidade do solo. Os indicadores mais comumente utilizados na literatura científica são suficientemente sensíveis para detectar diferenças de qualidade do solo de acordo com o uso da terra. Portanto, a seleção de um conjunto mínimo de dados representativos pode ser mais útil do que um conjunto complexo de atributos, para comparar sistemas de manejo quanto à qualidade do solo.

Termos para indexação: plantio direto, análise de componentes principais, funcionamento do solo, saúde do solo, manejo do solo, segurança do solo.

\section{Introduction}

Soil chemical, physical, and biological attributes (Karlen et al., 2001) have been used historically as proxies to soil quality (Andrews et al., 2002), which is a concept related to intrinsic characteristics of the soil, to its interactions with the ecosystem, and to the type of land use or management. This implies some degree of subjectivity as to individual perceptions of what can be deemed "good quality" (Velasquez et al., 2007; Blanco $\&$ Lal, 2008). More recently, the discussion has been centered on the concept of 'soil health', largely defined 
for soil biological properties (Doran \& Safley, 1997; Doran \& Zeiss, 2000). Both concepts are focused on assessing soil functions in the landscape, but there is no explicit reference state to be used in a soil quality or health framework.

Despite the large number of papers on soil quality in the literature, the concepts and tools in the research field are still being developed. McBratney et al. (2014) introduced the more complex concept of 'soil security', which deals with the conservation and improvement of the soil resources to produce food, fiber, freshwater, energy, and to help maintaining the climate sustainability and biodiversity. Nowadays, the research focus is on selecting, weighting, and interpreting a consensual set of indicators to assess soil quality (Lopes et al., 2013).

Soil quality indicators are normally chosen according to the research focus. The dataset of indicators may be constructed according to expert opinion (Andrews et al., 2002; Sánchez-Navarro et al., 2015), based on how often the parameters appear in scientific papers (Rousseau et al., 2012), or it may be guided solely on statistical criteria. Certainly, it can also consist of the combination of both strategies (Lima et al., 2013).

Although most authors assess soil quality using independent indicators, it is preferable to combine some of them into models, in order to create a soil quality index (SQI) that can provide integrated information about soil processes and functioning (Van Leeuwen et al., 2015). One of the approaches is related to the use of complex indices generated with a current knowledge of soil properties, obtained from a combination of several variables based on threshold values (Blanco $\&$ Lal, 2008). The SQI allows the determination of management (Fernandes et al., 2011) and plant species (Zhang et al., 2015) impacts on soil functions.

Many soil scientists have proposed more detailed procedures to evaluate soil quality by combining and integrating specific soil properties into soil quality indices (Doran \& Parkin, 1994; Karlen \& Stott, 1994). These procedures allow to weight various functions, depending on the research focus and on socioeconomic concerns. Proposed soil quality models are similar to SQI procedures as for the concepts and approachs, except that they include soil properties related to soil functions (regulation of hydrologic cycle, bioremediation of waste, carbon sequestration), in addition to the ones related to agricultural productivity.
Karlen \& Stott (1994) suggested a simple additive model that is widely used in the literature (Fernandes et al., 2011; Lima et al., 2013; Askari \& Holden, 2015; Nakajima et al., 2015).

Due to the variety of soil properties that can act as quality indicators, researchers should identify and select the most suitable ones according to the research goals (Nortcliff, 2002). However, comparing soil quality indicators is not an easy task, since there is neither a consensus as to the appropriate indicators to compose the SQI (Rousseau et al., 2012), nor as to the way that they should be selected to minimize personal subjectivity.

The objective of this work was to select soil quality indicators to be used in an additive model, in order to compare native and cultivated areas of Brazilian Cerrado.

\section{Materials and Methods}

The study was carried out in areas located in the Cerrado biome, in the state of Piauí, Brazil. Samples were collected from four distinct farms, in the following counties: Bom Jesus $\left(09^{\circ} 10^{\prime} 35^{\prime \prime} \mathrm{S}, 44^{\circ} 50^{\prime} 36^{\prime \prime} \mathrm{W}\right.$, at 600 $\mathrm{m}$ altitude), Sebastião Leal $\left(07^{\circ} 39^{\prime} 14^{\prime \prime} \mathrm{S}, 44^{\circ} 02^{\prime} 37^{\prime \prime} \mathrm{W}\right.$, at $450 \mathrm{~m}$ altitude), Uruçuí $\left(08^{\circ} 14^{\prime} 07^{\prime \prime} \mathrm{S}, 44^{\circ} 38^{\prime} 09^{\prime \prime} \mathrm{W}\right.$, at $550 \mathrm{~m}$ altitude), and Baixa Grande do Ribeira $\left(07^{\circ} 48^{\prime} 10^{\prime \prime} \mathrm{S}, 45^{\circ} 00^{\prime} 60^{\prime \prime} \mathrm{W}\right.$, at $600 \mathrm{~m}$ altitude).

The region's climate is tropical savanna, Aw, according to Köppen-Geiger's classification, and the predominant soil type of the sampled areas is Latossolo Amarelo (Oxisol) according to Santos et al. (2013). The predominant mineralogy consists of kaolinite, and Fe and Al oxides (Pragana, 2011).

Soil samples were collected from each selected area in March 2012, in two different management systems: no-tillage (NT) and conventional tillage (CT); and, in each farm, an adjacent plot of native cerrado (NC) was used as reference. Each farm consisted of a replicate for each soil management system with historic land use (Table 1). Samples were collected at the $0.0-0.1-\mathrm{m}$ soil depth.

The analyzed physical properties were: BD, bulk density; TP, total porosity; Mac, macroporosity; Mic, microporosity; Ksl, saturated hydraulic conductivity; $\theta \mathrm{s}$, moisture saturation; Es, effective saturation; PR, penetration resistance; AG1, aggregates larger than $2 \mathrm{~mm}$; AG2, aggregates between 2 and $1 \mathrm{~mm}$; AG3, aggregates between 2 and $0.5 \mathrm{~mm}$; AG4, aggregates 
between 0.5 and 0.25 ; AG5, aggregates smaller than 0.25; GMD, geometric mean diameter; and ASI, aggregate stability index. The chemical properties were: SOM, soil organic matter; $\mathrm{pH} ; \mathrm{Ca}^{2+}+\mathrm{Mg}^{2+}$, exchangeable calcium plus magnesium; available $\mathrm{P}$; total N; SB, sum of bases; $\mathrm{CEC}$, cation exchange capacity; exchangeable acidity $\left(\mathrm{Al}^{3+}\right) ; \mathrm{H}+\mathrm{Al}$, potential acidity; $\mathrm{m}$, aluminum saturation; and $\mathrm{V} \%$, base saturation. The biological properties were: $\mathrm{MBC}, \mathrm{C}$ in the microbial biomass; BR, basal respiration; qMic, microbial quotient; $\mathrm{qCO}_{2}$, metabolic quotient; TOC, total organic $\mathrm{C}$; TON, total organic $\mathrm{N}$; C Stk, carbon stock; N Stk, N stock (N Stk); and C/N ratio.

$\mathrm{BD}$ was calculated by the volumetric ring method, according to Donagema et al. (2011); PR was obtained using a penetrometer with a $4 \mathrm{~kg}$ piston (standard) impact, based on the transformation of rod penetration of the device into the ground (cm per impact); TP was determined according to Santos et al. (2011); Mac was calculated as the difference between total porosity of soil saturation and volume in equilibrium with the matric potential of $-60 \mathrm{hPa}$ (Santos et al., 2011.); Mic was obtained by the difference between Mac and TP; effective Mic was calculated according to Marchão et al. (2007); Ksl was obtained according to Donagema et al. (2011) and by the application of Darcy's equation; $\theta$ s was equal to the moisture of saturated soil; and Es was determined by the equation: $\mathrm{Es}=\theta_{\mathrm{s}}-\theta_{15,198.75}$.

The aggregates were separated by the wet method, according to Donagema et al. (2011), and aggregate classes were separated using mesh sieves. This method was also used to determine GMD and ASI. Particle size analysis was obtained with the pipette method (Donagema et al., 2011).

Table 1. Description of land use in the studied areas in the Brazilian Cerrado.

\begin{tabular}{|c|c|c|}
\hline Municipality & $\begin{array}{l}\text { Soil control } \\
\text { system }\end{array}$ & Description \\
\hline \multirow[b]{2}{*}{ Sebastião Leal } & $\mathrm{CT}$ & $\begin{array}{l}\text { Two years of millet (2010/2011) and soybean (2011/2012) cultivation. Disk harrow with dolomitic lime applied in two } \\
\text { seasons. Fertilized with NPK in the first year, and with NPK and FTE in the second year. }\end{array}$ \\
\hline & NT & $\begin{array}{l}\text { Cultivated for fourteen years, starting in } 1997 \text {, managed with disk harrow, general harrow, and dolomitic lime application. } \\
\text { No-tillage started in } 1998 / 1999 \text {. Cultivation of soybean from } 1998 \text { to } 2000 \text {, millet in 2000/2001, and soybean again from } \\
2001 \text { to } 2007 / 2008 \text {, followed by cotton in 2008/2009, maize in 2009/2010, and soybean until 2011/2012. Dolomitic } \\
\text { lime applied during the crop seasons } 1998 / 1999,2002 / 2003 \text { (with gypsum), 2006/2007, 2008/2009 (with gypsum), and } \\
2011 / 2012 \text {. Fertilized with: NPK and FTE, in the agricultural years } 1998 / 1999,1999 / 2000,2001 / 2002 \text {; NPK and Zn, in } \\
\text { 2000/2001; NPK, FTE, and KCl, in the crop seasons from 2002/2003 to 2007/2008, and in 2010/2011; SS, MAP, and } \\
\mathrm{KCl} \text { in 2008/2009. }\end{array}$ \\
\hline \multirow[b]{2}{*}{ Uruçuí } & $\mathrm{CT}$ & $\begin{array}{l}\text { Three years growing rice, soybean/millet, and soybean, each crop per year. Application of dolomitic lime in the crop } \\
\text { seasons } 2009 / 2010 \text { and 2011/2012; and rock phosphate in 2010/2011. Use of disc harrow in 2009/2010, and subsoiler in } \\
2010 / 2011 \text {. }\end{array}$ \\
\hline & NT & $\begin{array}{l}\text { Thirteen years of cultivation, starting in } 1999 \text {; soil managed with disc harrow, and application of dolomitic lime and NPK. } \\
\text { Growing rice in the crop seasons } 2000 / 2001 \text { and } 2001 / 2002 \text {; soybean, from } 2002 / 2003 \text { to } 2006 / 2007 \text {, and in } 2009 / 2010 \text {; } \\
\text { soybean/millet in } 2007 / 2008 \text { and } 2008 / 2009 \text {; maize in } 2010 / 2011 \text {; and soybean/beans in } 2011 / 2012 \text {. Application } \\
\text { of dolomitic lime, in the agricultural years } 2001 / 2002,2003 / 2004 \text {, and } 2008 / 2009 \text {. Fertilized with NPK and } \mathrm{KCl} \text { in } \\
\text { 2001/2002, 2006-2007/2008; SS and } \mathrm{KCl} \text { in } 2004 / 2005,2008-2009 / 2010 \text {, and in 2011/2012; and NPK, KCl, and urea in } \\
2010 / 2011 \text {. }\end{array}$ \\
\hline \multirow[b]{2}{*}{ Bom Jesus } & $\mathrm{CT}$ & $\begin{array}{l}\text { Two years growing beans, starting in 2009. Application of dolomitic lime in 2010/2011, SS, and } \mathrm{KCl} \text { in both crop seasons. } \\
\text { Use of disc harrow in 2010/2011, and harrow and leveler in 2011/2012. }\end{array}$ \\
\hline & NT & $\begin{array}{l}\text { Cultivation started in } 2002 \text {; soil managed from } 2002 \text { to } 2005 / 2006 \text { using conventional tillage. No-tillage started in } \\
\text { 2007/2008. Millet was cultivated from } 2006 / 2007 \text { to } 2008 / 2009 \text {, followed by annual soybean/millet succession. } \\
\text { Application of SS and } \mathrm{KCl} \text { in all growing seasons. }\end{array}$ \\
\hline \multirow{2}{*}{$\begin{array}{l}\text { Baixa Grande } \\
\text { do Ribeira }\end{array}$} & $\mathrm{CT}$ & $\begin{array}{l}\text { Sixteen years of cultivation, from } 1990 \text { onward, growing rice; soil preparation with disc harrow and leveler up to } \\
1994 / 1995 \text { (year of lime application). Area fallow until 1999; from 2000/2001 to 2009/2010 soybean cultivation followed } \\
\text { by soybean/millet. Disc harrow and leveler used in all years, lime and gypsum applications in } 2001 / 2002 \text {; and NPK } \\
\text { fertilizer applied from 2000/2001 until 2009/2010, followed by MAP and KCl in the last two years. }\end{array}$ \\
\hline & NT & $\begin{array}{l}\text { Cultivation started in 1990; the area was managed for four years under conventional tillage and left fallow between } \\
\text { 1995-2006. From 2006/2007 onward, cultivation of soybean/millet in all years under NT. Application of dolomitic lime } \\
\text { in 2006/2007, NPK in 2010/2011, and MAP and KCl in 2011/2012 }\end{array}$ \\
\hline
\end{tabular}

CT, conventional tillage; NT, no-tillage; FTE, fritted traced elements; Gafsa, natural phosphate of Gafsa; KCl, potassium chloride; MAP, monoammonium phosphate; NPK, formulation with nitrogen, phosphorus and potassium; AS, ammonium sulfate; SS, single superphosphate. 
Chemical analyses were performed according to Donagema et al. (2011). As to the biological properties, MBC was determined by the irradiation-extraction method, adapted from Islam \& Weil (1998); BR was determined according to Alef \& Nannipieri (1995); $\mathrm{qCO}_{2}$ was calculated using the ratio between BR and MBC; qMic was determined bythe ratio between MBC and TOC; TON was determined by the Kjeldahl method; C/N, C Stk, and N Stk were obtained by the equivalent layer method, considering TOC, TON, and BD levels according to Bayer et al. (2000).

The complete set of indicators consisted of a large number of physical, chemical, and biological soil properties representing indicators used in studies carried out worldwide. In this set, 36 parameters were used, among which all the physical, chemical, and biological soil properties previously described.

A subset was obtained from a selection of indicators based on the principal component analysis (PCA), using all variables in the whole set. The first criterion was to select variables with eigenvalues greater than one; subsequently, we selected, in each principal component, the variables with eigenvectors greater or equal to 0.7 (Andrews et al., 2002), which represents a high correlation with the respective principal component. With this procedure, 20 variables were selected, among which the soil physical properties BD, TP, Mac, Mic, Ksl, $\theta$ s, Es, AG5, GMD, and ASI; the soil chemical properties $\mathrm{Ca}^{2+}+\mathrm{Mg}^{2+}, \mathrm{K}^{+}, \mathrm{SB}, \mathrm{CEC}$, and $\mathrm{Al}^{3+}$; and the soil biological properties $\mathrm{MBC}, \mathrm{TOC}$, TON, N Stk.

A second subset was defined using indicators with the highest frequency of use in 33 studies in the scientific literature in the theme, including research randomly obtained from different regions, on different continents. This kind of data set is frequently used to discriminate or to certify the SQ (Andrews et al., 2002; Rousseau et al., 2012; Lima et al., 2013; Askari \& Holden, 2014). A selection of variables for this subset was performed based on a minimum frequency of $30 \%$ in the evaluated scientific papers. The subset consisted of 16 variables, including the physical parameters BD, Mac, Mic, Ksl, PR, GMD, and ASI; the chemical parameters $\mathrm{SOM}, \mathrm{pH}, \mathrm{P}, \mathrm{SB}$, and $\mathrm{T}$; and the biological parameters $\mathrm{MBC}, \mathrm{BR}, \mathrm{qCO}_{2}$, and $\mathrm{N}$ Stk.

The model proposed by Karlen \& Stott (1994), with modifications, was used to calculate SQI from the distinct data sets. Initially, four functions expressing soil quality were established: RSSW, receiving, storing, and supplying water; SSCN, storing, supplying, and cycling nutrients; PRG, promoting root growth; and PBA, promoting biological activity. These functions were represented by indicators which have intrinsic relationship with them. Because these indicators are expressed in different units, they were first converted into dimensionless values ranging from 0 to 1 . These values, or indicator scores, were obtained from the following equation (Wymore, 1993):

$$
\mathrm{v}=1 / 1+[(\mathrm{B}-\mathrm{L}) / \mathrm{x}-\mathrm{L}]^{2 \mathrm{~S}(\mathrm{~B}+\mathrm{x}-2 \mathrm{~L})}
$$

in which: $\mathrm{v}$ is the standard score; $\mathrm{B}$ is the indicator critical value, or threshold-base; L is the lower threshold; $\mathrm{S}$ is the slope of the tangent of the curve for the indicator threshold-base; and $\mathrm{x}$ is the value of the soil quality indicator parameter measured in the field.

An "S" value for each analyzed soil quality indicator was obtained with the following equation:

$$
\mathrm{S}=\left(\log \left(\frac{1}{\mathrm{n}}\right)-1\right) /\left(\frac{\mathrm{B}-\mathrm{L}}{\mathrm{x}-\mathrm{L}}\right) \times 2(\mathrm{~B}+2 \mathrm{x} \times \mathrm{L}) .
$$

The $\mathrm{S}$ value can express two types of standardized scores: the first one - "more is better" - was represented by indicators that desirably have greater values, like sum of bases; and the second one - "less is better" was related to indicators that desirably have smaller values, such as soil density.

The upper and lower threshold values, equivalent to the maximum and minimum values, were defined by specific technical and scientific recommendations for tropical soils (Kiehl, 1998; Ribeiro et al., 1999; Sousa \& Lobato, 2004; Blainski et al., 2008; Lopes et al., 2013).

After the indicator scores (standardized scores) were calculated, their weights were defined according to the indicator function, according to Chaer (2001), as: accommodating, retaining, and supplying water to plants; stocking and recycling nutrients; supporting plant growth; and promoting biological activity. These functions were considered in two different models (Table 2), one for the treatments (soil management systems), and one for the native Cerrado; the latter was aligned with the first, but without the soil chemical properties (except for SOM) (Souza, 2011), since the Cerrado soils have low $\mathrm{pH}$ and low nutrient levels, and 
show high levels of aluminum (Souza, 2011). Therefore, 36 SQI were calculated, which were composed of three management systems, three datasets, and four farms (replicates).

To weigh the indicators according to each function, we adopted 0.25 as the same weight for all of them, considering the same importance for all functions (Souza, 2011).

To obtain the SQI, the function score has to be calculated, which was done by adding the calculated values for the indicators associated with each function, which resulted in SQI ranging from 0 to 1 .

For the statistical analysis of the generated SQI with the three datasets, each farm was considered as a block (four replicates). The effects of management systems and procedures used to select the indicators were considered as sources of variation. SQI data were subjected to the analysis of variance, and their averages were compared using the Tukey's test, at 5\% probability. The statistical analysis was performed using the XLSTAT 2013 software (Addinsoft, New York, NY, USA).

Table 2. Functions and indicators for assessing the soil quality index.

\begin{tabular}{|c|c|c|c|c|c|c|}
\hline \multicolumn{3}{|c|}{ Function $^{(1)}$} & \multirow[t]{2}{*}{ Indicator } & \multirow[t]{2}{*}{ Score } & \multirow[t]{2}{*}{ Weight } & \multirow[t]{2}{*}{ Product } \\
\hline Score & Weight & Product & & & & \\
\hline \multicolumn{7}{|c|}{ Accommodating, retaining, and supplying water } \\
\hline \multirow[t]{4}{*}{$\mathrm{SF}_{1}$} & \multirow[t]{4}{*}{$\mathrm{WF}_{1}$} & \multirow[t]{4}{*}{$\mathrm{SF}_{1} \cdot \mathrm{WF}_{1}$} & 1.1 & $\mathrm{SI}_{1.1}$ & $\mathrm{WI}_{1.1}$ & $\mathrm{SI}_{1.1} \cdot \mathrm{WI}_{1.1}$ \\
\hline & & & 1.2 & $\mathrm{SI}_{1.2}$ & $\mathrm{WI}_{1.2}$ & $\mathrm{SI}_{1.1} \cdot \mathrm{WI}_{1.2}$ \\
\hline & & & $1 . n$ & $\mathrm{SI}_{1 . \mathrm{n}}$ & $\mathrm{WI}_{1 . \mathrm{n}}$ & $\mathrm{SI}_{1 . \mathrm{n}} \cdot \mathrm{WI}_{1 . \mathrm{n}}$ \\
\hline & & & & & & $\sum=\mathrm{SF}_{1}$ \\
\hline \multirow{5}{*}{$\mathrm{SF}_{2}$} & \multicolumn{5}{|c|}{ Stocking and recycling nutrients } & \\
\hline & $\mathrm{WF}_{2}$ & $\mathrm{SF}_{2} . \mathrm{WF}_{2}$ & 2.1 & $\mathrm{SI}_{1.1}$ & $\mathrm{WI}_{2.1}$ & $\mathrm{SI}_{2.1} \cdot \mathrm{WI}_{2.1}$ \\
\hline & & & 2.2 & $\mathrm{SI}_{1.2}$ & $\mathrm{WI}_{2.2}$ & $\mathrm{SI}_{2.1} \cdot \mathrm{WI}_{2.2}$ \\
\hline & & & $2 . n$ & $\mathrm{SI}_{1 . \mathrm{n}}$ & $\mathrm{WI}_{2 . \mathrm{n}}$ & $\mathrm{SI}_{2 . \mathrm{n}} \cdot \mathrm{WI}_{2 \cdot \mathrm{n}}$ \\
\hline & & & & & & $\sum=\mathrm{EF}_{2}$ \\
\hline \multirow{5}{*}{$\mathrm{SF}_{3}$} & \multicolumn{5}{|c|}{ Promote plant growth } & \\
\hline & $\mathrm{WF}_{3}$ & $\mathrm{SF}_{3} . \mathrm{WF}_{3}$ & 3.1 & $\mathrm{SI}_{3.1}$ & $\mathrm{WI}_{3.1}$ & $\mathrm{SI}_{3.1} \cdot \mathrm{WI}_{3.1}$ \\
\hline & & & 3.2 & $\mathrm{SI}_{3.2}$ & $\mathrm{WI}_{3.2}$ & $\mathrm{SI}_{3.1} \cdot \mathrm{WI}_{3.2}$ \\
\hline & & & $3 . n$ & $\mathrm{SI}_{3 . \mathrm{n}}$ & $\mathrm{WI}_{3 . \mathrm{n}}$ & $\mathrm{SI}_{3 \cdot \mathrm{n} \cdot \mathrm{WI}} \cdot \mathrm{I}_{3 \cdot \mathrm{n}}$ \\
\hline & & & & & & $\sum=\mathrm{SF}_{3}$ \\
\hline \multirow{5}{*}{$\mathrm{SF}_{4}$} & \multicolumn{5}{|c|}{ Promote biological activity } & \\
\hline & $\mathrm{WF}_{4}$ & $\mathrm{SF}_{4} \cdot \mathrm{WF}_{4}$ & 4.1 & $\mathrm{SI}_{4.1}$ & $\mathrm{WI}_{4.1}$ & $\mathrm{SI}_{4.1} \cdot \mathrm{WI}_{4.1}$ \\
\hline & & & 4.2 & $\mathrm{SI}_{4.2}$ & $\mathrm{WI}_{4.2}$ & $\mathrm{SI}_{4.1} \cdot \mathrm{WI}_{4.2}$ \\
\hline & & & $4 . n$ & $\mathrm{SI}_{4 . \mathrm{n}}$ & $\mathrm{WI}_{4 . \mathrm{n}}$ & $\mathrm{SI}_{4, \mathrm{n}} \cdot \mathrm{WI}_{4, \mathrm{n}}$ \\
\hline & & $\sum=\mathrm{SQI}$ & & & & $\sum=\mathrm{SF}_{4}$ \\
\hline
\end{tabular}

(1)According to Chaer (2001). SF, function score; WF, function weight; SI, indicator score; WI, indicator weight; and SQI, soil quality index.

\section{Results and Discussion}

Soil quality indices for the three soil management systems, obtained with the arithmetic mean of 12 SQI (4 farms x 3 datasets), irrespective of the method used to select the parameters are presented in Figure 1.

The management systems led to a soil quality decrease, compared to the Cerrado soil, which showed higher SQI than the disturbed areas. The incorporation of native areas for agricultural purposes changes the soil properties reducing soil quality, mainly in tropical regions (Pragana, 2011). In the Cerrado, the replacement of native forests for agriculture is usually accompanied by a sharp decrease of the SOM levels. As a result, the soil aggregate stability (Mataix-Solera et al., 2011) - a sound indicator of soil physical quality (Marchão et al., 2007) - reduces. The decline of soil quality observed in this region due to agricultural management systems are mainly related to these factors.

The no-tillage system did not show soil quality statiscally greater than that of the conventional system. According to the classification proposed by Marzaioli et al. (2010), the area under NC showed the highest soil quality $(\mathrm{SQI}>0.7)$ and the agricultural systems $(\mathrm{NT}$ and $\mathrm{CT})$ had an intermediate soil quality $(0.55<\mathrm{SQI}<0.7)$. The quality of the CT, however, was very close (SQI approximately 0.57 ) to the lower class. Areas under CT

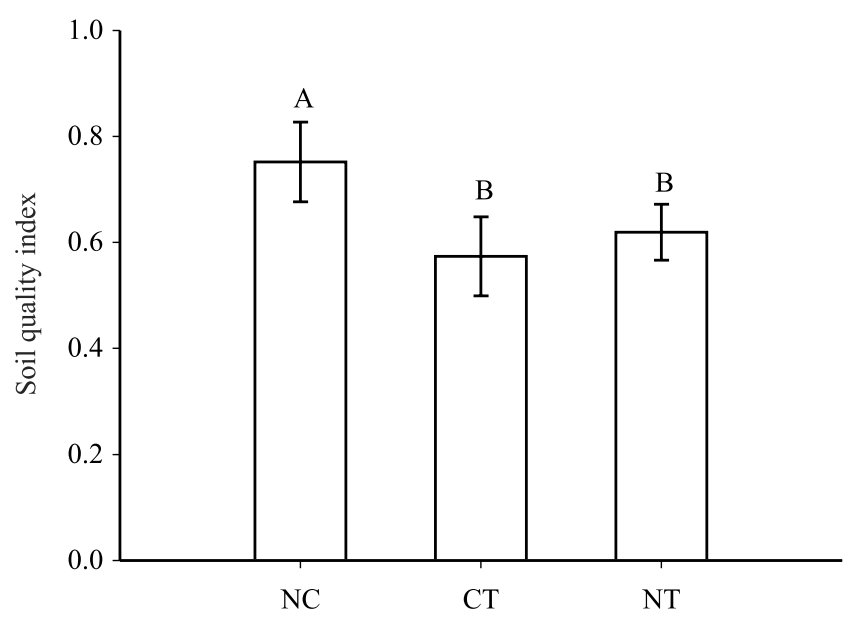

Figure 1. Soil quality index (SQI) according to the soil management systems, irrespective of the dataset. SQI means followed by equal letters do not differ by the Tukey's test, at $5 \%$ probability. $\mathrm{NC}$, native area in Cerrado; $\mathrm{CT}$, conventional tillage; and NT, no-tillage.

Pesq. agropec. bras., Brasília, v.51, n.9, p.1643-1651, set. 2016 DOI: 10.1590/S0100-204X2016000900064 
are negatively affected, mainly due to the reduction of organic C (Osgoz et al., 2013).

The short adoption time of the treatments for most of the assessed areas (Table 1) contributed to the absence of differences between CT and NT, evidencing the need for further studies, as pointed out by Nakajima et al. (2015). In the Brazilian Cerrado, Costa et al. (2006) and Pragana (2011) also reported that the short adoption time for management systems were not able to promote differences in soil quality between conventional and conservation tillage systems.

Studies indicate that not tilling the soil favors the sustainability of agroecosystems, with pronounced effects on systems with long-term deployment (Fernandes et al., 2011; Souza, 2011). In addition, SQIs should be useful to differentiate between degradion statuses of agricultural soils, and can be used in monitoring and assessing the best agricultural managements.

The SQI obtained from the 36 parameters (complete indicator dataset, $\mathrm{CD}$ ), as well as from the subset formed with the most published parameters in scientific literature, and from the subset built using principal component analysis (PCA) are shown in Figures 2 and 3.

The SQI analysis obtained with the CD dataset was not able to detect differences between soil quality

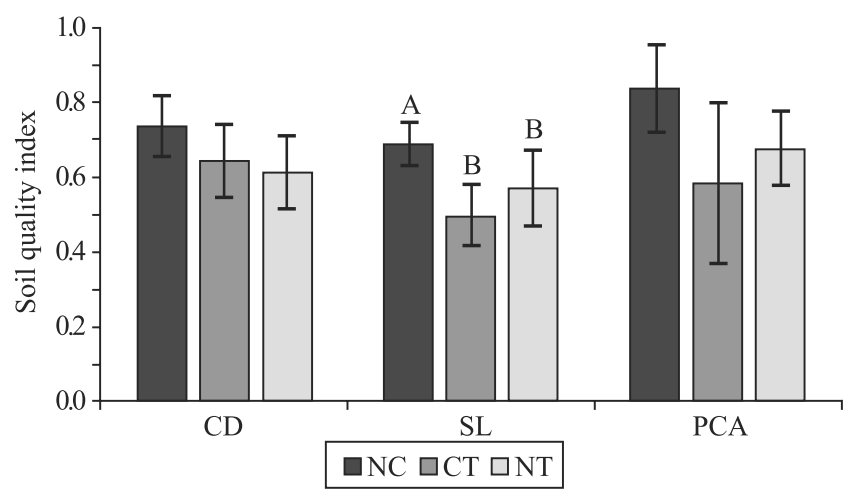

Figure 2. Soil quality indices (SQI) obtained with the use of each of the studied datasets, according to the soil management systems. SQI means followed by equal letters do not differ by the Tukey's test, at $5 \%$ probability. $\mathrm{CD}$, complete dataset; SL, indicators selected according to the scientific literature; PCA, indicators selected using principal component analysis in $\mathrm{CD}$; NC, native cerrado; CT, conventional tillage; NT, no-tillage. Bars represent standard deviation of the mean. of the native Cerrado and that of the managed areas (Figure 2). This dataset shows a high SQI variability between sampled areas, including the $\mathrm{NC}$ ones. A dataset with many variables, as in the case of $\mathrm{CD}$, complicates the determination of individual parameter values, requiring a greater researcher subjectivity and, therefore, increasing the risk of overestimating or underestimating soil indicators, with great implications on SQI. Moreover, many of soil properties are not good indicators of soil quality and, therefore, should not be included for obtaining the SQI (Rousseau et al., 2012).

The SQIs obtained by using a subset of commonly used parameters in the scientific literature was able to distinguish between native and disturbed areas of Brazilian Cerrado. Furthermore, this subset was able to synthesize complex information contained in a large set of variables. Therefore, adopting a 30\% frequency level of presence in the scientific literature is an alternative criterion for selecting the indicators that would comprise the minimum dataset (MD) to generate SQIs for the Brazilian Cerrado.

Among the analyzed datasets, that of the scientific literature contains the smallest number of selected variables, and a smaller and less complex MD is desirable (Askari \& Holden, 2015) for distributing and weighing soil quality indicators within the detailed functions in the model (Rousseau et al., 2012).

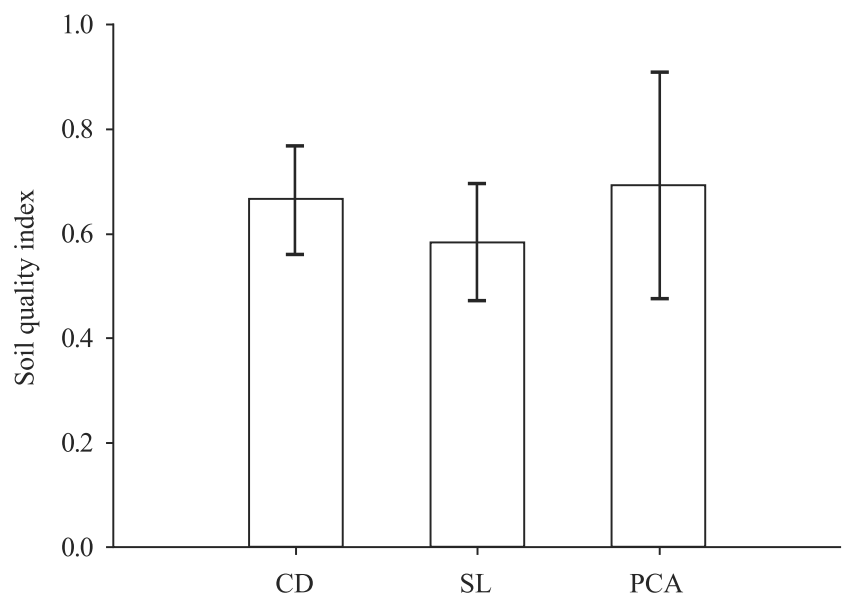

Figure 3. Soil quality index (SQI) according to the indicator dataset, irrespective of the management systems. CD, complete dataset; SL, indicators selected according to the scientific literature; and PCA, indicators selected using principal component analysis in CD. Bars represent standard deviation of the mean. 
As previously stated, many variables complicate the determination of individual parameter values, depending on the employed subjectivity, which has direct implications on the value assigned to SQI. In addition, other practical benefits must be highlighted by adopting a reduced MD, such as a reduction of the sampling time and of the collection and analysis costs.

Several authors have shown that soil quality can be assessed by selecting a smaller number of indicator properties from a larger dataset (Rousseau et al., 2012; Lima et al., 2013).

Similarly to what was observed with $C D$, the dataset obtained with the PCA procedure was also not sensitive to indicate differences of SQIs between soil management systems. This dataset provided high standard deviation for SQI, with high values for minimum significant differences between land use systems, which shows low sensitivity for the discrimination of management systems in areas with great complexity in their historic of use, such as in the assessed farms.

Therefore, using the PCA for selecting soil indicators to determine soil quality was not a successful procedure in distinguishing soil quality due to the management adopted, as it was highlighted in other instances (Andrews et al., 2002). These authors showed that the dataset of PCA was compared to expert opinion, and both methods were able to represent variability in the experimental conditions. Moreover, Askari \& Holden (2014) argue that this mathematical approach of SQI determination has advantages. Although, in the present work, PCA was not sufficiently sensitive to differentiate SQI in the areas of Cerrado, this method has been highlighted as a viable alternative to variable selection, since it is used as a tool to "filter" data, and it allows to visualize which parameters are more relevant, permitting a reduction of the necessary data amount, making it possible the use of MD, such as those used by Askari \& Holden (2014, 2015), Ngo-Mbogba et al. (2015), and Sánchez-Navarro et al. (2015).

The different datasets used to select soil quality indicators, considering all management systems together, did not provide significantly different SQIs (Figure 3). Maintaining soil quality at a desired level is complicated because of the complex interactions between soil, climate, vegetation, and management. This fact stimulates studies aimed at generating and validating models, in order to facilitate monitoring the impacts of land use and management according to their
SQIs, which enables the early detection of changes of soil quality (Sánchez-Navarro et al., 2015).

\section{Conclusions}

1. The combined analysis of soil quality indices (SQI), irrespective of the dataset used for selecting the indicators, shows that soil quality decreases with the incorporation of native areas for agriculture in the Brazilian Cerrado.

2. Among the studied datasets, the one that uses the most common soil quality indicators in the scientific literature is sufficiently sensitive to detect differences in SQIs according to land use and management.

3. The selection of a minimum set of representative indicators can be more useful than a complex set to obtain adequate SQIs.

\section{References}

ALEF, K.; NANNIPIERI, P. (Ed.). Methods in applied soil microbiology and biochemistry. London: Academic Press, 1995. $576 \mathrm{p}$.

ANDREWS, S.S.; KARLEN, D.L.; MITCHELL, J.P. A comparison of soil quality indexing methods for vegeTable production systems in Northern California. Agriculture, Ecosystems and Environment, v.90, p.25-45, 2002. DOI: 10.1016/S0167-8809(01)00174-8.

ASKARI, M.S.; HOLDEN, N.M. Indices for quantitative evaluation of soil quality under grassland management. Geoderma, v.230/231, p.131-142, 2014. DOI: 10.1016/j.geoderma.2014.04.019.

ASKARI, M.S.; HOLDEN, N.M. Quantitative soil quality indexing of temperate arable management systems. Soil and Tillage Research, v.150, p.57-67, 2015. DOI: 10.1016/j.still.2015.01.010.

BAYER, C.; MIELNICZUK, J.; AMADO, T.J.C.; MARTINNETO, L.; FERNANDES, S.V. Organic matter storage in a sandy clay loam Acrisol affected by tillage and cropping systems in southern Brazil. Soil and Tillage Research, v.54, p.101-109, 2000. DOI: 10.1016/S0167-1987(00)00090-8.

BLAINSKI, E.; TORMENA, C.A.; FIDALSKI, J.; GUIMARÃES, R.M.L. Quantificação da degradação física do solo por meio da curva de resistência do solo à penetração. Revista Brasileira de Ciência do Solo, v.32, p.975-983, 2008. DOI: 10.1590/S010006832008000300007.

BLANCO, H.; LAL, R. Principles of soil conservation and management. Dordrecht: Springer, 2008. 617p. DOI: 10.1007/978-1-4020-8709-7.

CHAER, G.M. Modelo para determinação de índice de qualidade do solo baseado em indicadores físicos, químicos e microbiológicos. 2001. 100p. Dissertação (Mestrado) Universidade Federal de Viçosa, Viçosa.

COSTA, E.A.; GOEDERT, W.J.; SOUSA, D.M.G. de. Qualidade de solo submetido a sistemas de cultivo com preparo convencional 
e plantio direto. Pesquisa Agropecuária Brasileira, v.41, p.11851191, 2006. DOI: 10.1590/S0100-204X2006000700016.

DORAN, J.W.; PARKIN, T.B. Defining and assessing soil quality. In: DORAN, J.W.; COLEMAN, D.C.; BEZDICEK, D.F.; STEWART, B.A. (Ed.). Defining soil quality for a sustainable environment. Madison: Soil Science Society of America, 1994. p.3-21. (SSSA. Special publication, 35). DOI: 10.2136/ sssaspecpub35.c1.

DORAN, J.W.; SAFLEY, M. Defining and assessing soil health and sustainable productivity. In: PANKHURST, C.; DOUBE, B.M.; GUPTA, V.V.S.R. (Ed.). Biological indicators of soil health. Wallingford: CAB International, 1997. p.1-28.

DORAN, J.W.; ZEISS, M.R. Soil health and sustainability: managing the biotic component of soil quality. Applied Soil Ecology, v.15, p.3-11, 2000. DOI: 10.1016/S09291393(00)00067-6.

DONAGEMA, G.K.; CAMPOS, D.V.B. de; CALDERANO, S.B.; TEIXEIRA, W.G.; VIANA, J.H.M. (Org.). Manual de métodos de análise de solo. 2.ed. rev. Rio de Janeiro: Embrapa Solos, 2011. 212p. (Embrapa Solos. Documentos, 132).

FERNANDES, J.C.; GAMERO, C.A.; RODRIGUES, J.G.L.; MIRÁS-AVALO, J.M. Determination of the quality index of a Paleudult under sunflower culture and different management systems. Soil and Tillage Research, v.112, p.167-174, 2011. DOI: 10.1016/j.still.2011.01.001.

ISLAM, K.R.; WEIL, R.R. Microwave irradiation of soil for routine measurement of microbial biomass carbon. Biology and Fertility of Soils, v.27, p.408-416, 1998. DOI: 10.1007/s003740050451.

KARLEN, D.L.; ANDREWS, S.S.; DORAN, J.W. Soil quality: current concepts and applications. Advances in Agronomy, v.74, p.1-40, 2001. DOI: 10.1016/S0065-2113(01)74029-1.

KARLEN, D.L.; STOTT, D.E. A framework for evaluating physical and chemical indicators of soil quality. In: DORAN J.W., COLEMAN, D.C.; BEZDICEK, D.F.; STEWART, B.A (Ed.). Defining soil quality for a sustainable environment. Madison: Soil Science Society of America, 1994. p.53-72. (SSSA. Special publication, 35).

KIEHL, E.J. Manual de compostagem: maturação e qualidade do composto. Piracicaba, 1998. 171p.

LIMA,A.C.R.; BRUSSAARD, L.; TÓTOLA, M.R.; HOOGMOED, W.B.; GOEDE, R.G.M. A functional evaluation of three indicators sets for assessing soil quality. Applied Soil Ecology, v.64, p.194200, 2013. DOI: 10.1016/j.apsoil.2012.12.009.

LOPES, A.A. de C.; SOUSA, D.M.G. de; CHAER, G.M.; REIS JUNIOR, F.B. dos; GOEDERT, W.J.; MENDES, I. de C. Interpretation of microbial soil indicators as a function of crop yield and organic carbon. Soil Science Society of America Journal, v.77, p.461-472, 2013. DOI: 10.2136/sssaj2012.0191.

MARCHÃO, R.L.; BALBINO, L.C.; SILVA, E.M. da; SANTOS JUNIOR, J. de D.G. dos; SÁ, M.A.C. de; VILELA, L.; BECQUER, T. Qualidade física de um Latossolo Vermelho sob sistemas de integração lavoura-pecuária no Cerrado. Pesquisa Agropecuária Brasileira, v.41, p.1531-1539, 2007. DOI: 10.1590/S0100204X2007000600015.
MARZAIOLI, R.; ASCOLI, R.D'.; PASCALE, R.A. de; RUTIGLIANO, F.A. Soil quality in a Mediterranean area of Southern Italy as related to different land use types. Applied Soil Ecology, v.44, p.205-212, 2010. DOI: 10.1016/j.apsoil.2009.12.007.

MATAIX-SOLERA, J.; CERDÀ, A.; ARCENEGUI, V.; JORDÁN, A.; ZAVALA, L.M. Fire effects on soil aggregation: a review. Earth-Science Reviews, v.109, p.44-60, 2011. DOI: 10.1016/j. earscirev.2011.08.002.

MCBRATNEY, A.; FIELD, D.J.; KOCH, A. The dimensions of soil security. Geoderma, v.213, p.203-213, 2014. DOI: 10.1016/j. geoderma.2013.08.013.

NAKAJIMA, T.; LAL, R.; JIANG, S. Soil quality index of a crosby silt loam in central Ohio. Soil and Tillage Research, v.146, p.323328, 2015. DOI: 10.1016/j.still.2014.10.001.

NGO-MBOGBA, M.; YEMEFACK, M.; NYECK, B. Assessing soil quality under different land cover types within shifting agriculture in South Cameroon. Soil and Tillage Research, v.150, p.124-131, 2015. DOI: 10.1016/j.still.2015.01.007.

NORTCLIFF, S. Standardization of soil quality attributes. Agriculture, Ecosystems and Environment, v.88, p.161-168, 2002. DOI: 10.1016/S0167-8809(01)00253-5.

OSGOZ, E.; GUNAL, H.; ACIR, N.; GOKMEN, F.; BIROL, M.; BUDAK, M. Soil quality and spatial variability assessment of land use effects in a typic Haplustoll. Land Degradation and Development, v.24, p.277-286, 2013. DOI: 10.1002/ldr.1126.

PRAGANA, R.B.Caracterização pedológica e diagnóstico da qualidade de solos sob plantio direto na Serra do Quilombo, sudoeste piauiense. 2011. 159p. Tese (Doutorado) - Universidade Federal Rural de Pernambuco, Recife.

RIBEIRO, A.C.; GUIMARÃES, P.T.G.; ALVAREZ V., V.H. (Ed.). Recomendações para o uso de corretivos e fertilizantes em Minas Gerais: 5. aproximação. Viçosa: Comissão de Fertilidade do Solo do Estado de Minas Gerais, 1999. 359p.

ROUSSEAU, G.X.; DEHEUVELS, O.; RODRIGUES ARIAS, I.; SOMARRIBA, E. Indicating soil quality in cacao-based agroforestry systems and old-growth forest: the potential of soil macrofauna assemblage. Ecological Indicators, v.23, p.535-543, 2012. DOI: 10.1016/j.ecolind.2012.05.008.

SÁNCHEZ-NAVARRO, A.; GIL-VÁSQUEZ, J.M.; DELGADOINIESTA, M.J.; MARÍN-SANLEANDRO, P.; BLANCOBERNARDEAU, A.; ORTIZ-SILLA, R. Establishing an index and identification of limiting parameters of characterizing soil quality in Mediterranean ecosystems. Catena, v.131, p.35-45, 2015. DOI: 10.1016/j.catena.2015.02.023.

SANTOS, G.G.; MARCHÃO, R.L.; SILVA, E.M. da; SILVEIRA, P.M. da; BECQUER, T. Qualidade física do solo sob sistemas de integração lavoura-pecuária. Pesquisa Agropecuária Brasileira, v.46, p.1339-1348, 2011. DOI: 10.1590/S0100204X2011001000030.

SANTOS, H.G. dos; JACOMINE, P.K.T.; ANJOS, L.H.C. dos; OLIVEIRA, V.A. de; LUMBRERAS, J.F.; COELHO, M.R.; ALMEIDA, J.A. de; CUNHA, T.J.F.; OLIVEIRA, J.B. de. Sistema brasileiro de classificação de solos. 3.ed. rev. e atual. Brasília: Embrapa, 2013. 353p. 
SOUSA, D.M.G. de; LOBATO, E. (Ed.). Cerrado: correção do solo e adubação. 2.ed. Brasília: Embrapa Informação Tecnológica; Planaltina: Embrapa Cerrados, 2004. 416p.

SOUZA, L.M. de. Atributos químicos, físicos e biológicos, estrutura de comunidades bacterianas e qualidade de solos de Cerrado sob plantio direto e preparo convencional. 2011. 203p. Tese (Mestrado) - Universidade de Brasília, Brasília.

VAN LEEUWEN, J.P.; LEHTINEN, T.; LAIR, G.J.; BLOEM, J.; HEMERIK, L.; RAGNARSDÓTTIR, K.V.; GÍSLADÓTTIR, G.; NEWTON, J.S.; DE RUITER, P.C. An ecosystem approach to assess soil quality in organically and conventionally managed farms in Iceland and Austria. Soil, v.1, p.83-101, 2015. DOI: 10.5194/soil-1-83-2015.
VELASQUEZ, E.; LAVELLE, P.; ANDRADE, M. GISQ, a multifunctional indicator of soil quality. Soil Biology and Biochemistry, v.39, p.3066-3080, 2007. DOI: $10.1016 / \mathrm{j}$. soilbio.2007.06.013.

WYMORE, A.W. Model-based systems engineering: an introduction to the mathematical theory of discrete systems and to the tricotyledon theory of system design. Boca Raton: CRC Press, 1993. 710p.

ZHANG, K.; ZHENG, H.; CHEN, F.L.; OUYANG, Z.Y.; WANG, Y.; WU, Y.F.; LAN, J.; FU, M.; XIANG, X.W. Changes in soil quality after converting Pinus to Eucalyptus plantations in southern China. Solid Earth, v.6, p.115-123, 2015. DOI: 10.5194/se-6-1152015.

Received on August 30, 2015 and accepted on March 3, 2016 